\title{
Student characteristics and knowledge on ODL concepts at first registration
} A case study from OUSL

\author{
K.A.J.M. Kuruppuarachchi and K.O.L.C. Karunanayake \\ Department of Botany, The Open University of Sri Lanka, \\ Nawala, Sri Lanka
}

\begin{abstract}
Purpose - The purpose of this paper is to identify socio-economic/demographic characteristics and to evaluate the knowledge on different open distance learning (ODL) concepts of BSc undergraduates of The Open University of Sri Lanka (OUSL) at first registration.

Design/methodology/approach - The surveying technique was adapted with a piloted structured questionnaire consisting of two components. The structured component was used to evaluate personal, socioeconomic and demographic data. The open ended component evaluated the student's perception on ODL concepts. The questionnaire was randomly adapted to 456 (35 percent Colombo Regional Centre (CRC) registrants) prospective $\mathrm{BSc}$ undergraduates at first registration time at the $\mathrm{CRC}$ in 2014 . Data collected from the structured component were frequency tabulated and cross-tabulated with the SPSS computer software. Responses of the open ended part were examined, categorized and the frequency percentages of each response category were calculated.

Findings - The structured component recognized that the majority of BSc undergraduates of the OUSL represent employed (53 percent), late adolescents (92 percent below age 27) who reside in rural or semi-urban areas (75 percent). They belong mostly to the lower middle class and 69 percent are from families which have a monthly family income below SLR30,000/(USD208). Answers of the open ended component on ODL concepts recognized that, prior knowledge on ODL concepts were developed by most BSc undergraduates. Approximately 50 percent of respondents perceived OUSL as an institute which facilitates working people by conducting part time-based or distance mode education with self-learning features. In total, 56.9 percent students perceived the role of an ODL teacher correctly as a facilitator or a guide. The educational process was perceived correctly as an ODL system by 52 percent, while the remainder also identified the system to be a more self-study and student centered flexible learning system. However, the role of a BSc student at OUSL was recognized as self-independent learners by only 36.7 percent and the majority had no clear perception of the role they have to play as an ODL student. Hence, more attention should be paid to make students recognize the role they have to play in an ODL system in order to succeed at OUSL.

Originality/value - Although research has been carried out periodically on the process of ODL education system at OUSL, on the graduate (output) and dropouts, etc., not many have focused on the nature of input such as characteristic features of first registrant and their prior knowledge on ODL. As the output invariably depends on the input and the process, this type of survey is timely and novel.
\end{abstract}

Keywords Open and distance education (ODE), BSc undergraduate, First registrant, ODL concepts, OUSL, Teaching methodology

Paper type Case study

(C) K.A.J.M. Kuruppuarachchi and K.O.L.C. Karunanayake. Published in the Asian Association of Open Universities Journal. Published by Emerald Publishing Limited. This article is published under the Creative Commons Attribution (CC BY 4.0) licence. Anyone may reproduce, distribute, translate and create derivative works of this article (for both commercial and non-commercial purposes), subject to full attribution to the original publication and authors. The full terms of this licence may be seen at $\mathrm{http} / / /$ creativecommons.org/licences/by/4.0/legalcode

\section{characteristics and ODL knowledge}

Received 12 November 2016 Revised 30 January 2017 Accepted 3 February 2017 
AAOUJ

12,1

42

\section{Introduction}

Teaching at a distance is characterized by separation of teacher and learner and learner from the learning group, by replacing interpersonal face-to-face communication of conventional education by an impersonal mode of communication mediated by technology (Keegan, 1996). At present, distance education systems and open education have become a feasible and viable alternative to those who were denied education due to one reason or the other (Nigam and Joshi, 2007). Although subjects dealing with humanities and social sciences have been offered through open distance learning (ODL) in the absence of major constraints, teaching science and technology courses through ODL is more challenging, mainly due to intensive practical work (Nigam and Joshi, 2007). Student dropout rates in ODL higher education systems are typically higher than in face-to-face conventional systems of higher education (Barefoot, 2004), and a study focusing dropouts of the BSc degree program at the Indira Gandhi National Open University, India (Fozdar et al., 2006) has come out with several significant issues faced by students. The lack of time (due to employment, family commitments), distance to study centers, absence of interaction with students, insufficient academic support, expectations of the program not being met and financial constraints were some of the key issues identified in this study. Investigations by Aluwihare and De Silva (2016) demonstrate that similar reasons contribute toward the prolonged time duration taken toward completing the Engineering degrees at the Open University of Sri Lanka (OUSL).

In the Sri Lankan context, OUSL is the premier and only state ODL institution where students can pursue their studies through ODL methodology. Established in 1980 following the Open University UK concept, the institute has the same legal and academic status as any other national university in Sri Lanka. Due to the nature of its teaching methodology and infrastructure, the OUSL is able to serve a large student population spread throughout the country. Data for 2015 indicate that it caters to 42,911 students, in either the Central campus in Nawala (Colombo Regional center) or in any one of the other seven regional centers in Kandy, Matara, Jaffna, Anuradhapura, Badulla, Kurunegala or Batticaloa. The University has five faculties: Natural Sciences, Health Sciences, Engineering Technology, Humanities and Social Sciences and Education.

The Faculty of Natural Sciences conducts several study programs such as short courses, diploma programs, certificate programs, etc. However, the Faculty's primary concern is the degree program leading to the BSc degree. As at 2015, 4,261 students were registered for and following the BSc degree program at OUSL and approximately 1,300 students enroll annually.

Unlike in the other state universities, the students enrolling to follow degree programs at OUSL are comparatively diverse (Jayathilake et al., 1997). Tantrigoda et al. (2014) state that as the majority of students enrolling for the BSc degree are adolescents who have undergone formal education, shifting to distance education with self-learning maybe a totally new experience for them. Students sometimes opt for ODL expecting it to be easy (Carnevale, 2000) and often face huge difficulties when they realize ODL requires equal if not more effort than conventional education (Fozdar and Kumar, 2006). Further, Kuruppuarachchi et al. (2016) ascertain that, the components of the education processing system (PS) of the OUSL play a comparatively different role to that of a conventional university and that the input (students enrolling) and process are comparatively different in ODL, but the quality of output (the graduate) should be equal or higher than that of a conventional setup. Evaluation of the nature of input of PS is very important for future educational strategic changes and for efficient quality products Kuruppuarachchi et al. (2016). Due to these reasons the present study was carried out with 456 (35 percent) prospective BSc undergraduates of OUSL at first registration at the Colombo Regional Centre (CRC) in the 2013/2014 academic year. The total number of new registrants for the BSc degree program at OUSL was 2,373 in the 2013/2014 academic year. Of this 55 percent 
registered at CRC. The survey explores the existing knowledge on ODL concepts of these prospective students while also attempting to get an insight into the socio-economic background characteristics of these students, in the view that the findings of the study will help ODL managers/administrators to make future direction of the BSc degree program.

\section{Methodology}

The surveying technique was adapted with a piloted structured questionnaire. The questionnaire consisted of two components. The first (structured) component: with 14 sections was used to evaluate personal, socio-economic and demographic data (Kuruppuarachchi and Gunerathne, 2014), while the open ended component facilitated the recognition of student's existing perceptions on varying ODL concepts. The questionnaire was randomly distributed at the CRC (Central campus) and collected from 456 (35 percent of students registered at $\mathrm{CRC}$ ) prospective $\mathrm{BSc}$ undergraduates of OUSL at first registration for the academic year 2013/2014. The statistics for BSc student enrollment clearly shows that all other six regional centers and 18 study centers belonging to OUSL collectively represent only 45 percent of the new registrant population. As 55 percent of new registrants are at $\mathrm{CRC}$, it seems justifiable to collect data from $\mathrm{CRC}$ and generalize results of the study for BSc undergraduates of OUSL.

\section{Statistical analyses}

Quantification of responses of the structured component. Data of responses of the first component (structured component) of the questionnaire were used to make a frequency tabulation test with the SPSS computer package.

Quantification of responses of the open ended component. The open ended questions received diverse as well as similar responses. Some seemingly different responses tended to have similar meanings. All responses were carefully examined and then the main categories were chosen. Each individual response was analyzed and placed in the relevant category. Quantification of each similar category of responses of the open ended part was carried out by calculating frequency percentages of each response category as follows (Kuruppuarachchi and Gunerathne, 2014; American Association for Public Opinion Research, 2000):

$$
\begin{aligned}
& \text { Frequency percentage of " } X \text { " }- \text { category of responses } \\
& =\frac{\text { Number of responses belong to " } X \text { " category }}{\text { Total number of responses for the open ended part }} \times 100
\end{aligned}
$$

The open ended part of the questionnaire was adapted to explore the prior knowledge of BSc undergraduate of OUSL on "different ODL concepts." This consisted of four parts. These are: teaching-learning process of OUSL; main instructional media used in OUSL; the role of the teacher of OUSL; the future role as an OUSL student. The responses provided were scrutinized with an open mind, without any restrictions, discrimination or preformed perceptions. The responses of students for each part were categorized, then quantified and are presented as described under the result and discussion section.

\section{Results and discussion}

\section{Structured component}

The results of the structured component of the questionnaire describe the socio-economic characteristics of BSc first registrants of OUSL. 
AAOUJ

12,1

44
Figure 1.

Monthly family income (US $\$ 1=$ SLR150) of new registrants for the $\mathrm{BSc}$ degree at OUSL
The highest educational qualification of parents or any other family member of most registrants was found to be (ca. 84 percent) below G.C.E. (A/L). This implies that the majority of parents are middle class employees. Further, the permanent residences of the new registrant to the BSc degree are mainly rural or semi-urban (74.4 percent). The monthly mean household income in year 2012 of Sri Lankan people was recognized as Urban (USD471), rural (USD291), estate sector (USD220), respectively (Department of Census and Statistics, 2013). Result of the study show that the majority of students registered for the BSc degree program in 2013/2014 academic year belong to the low income category. That is, the total monthly family income is less than SLR30,000/-(USD208) for 68.8 percent (Figure 1). The government policy of Sri Lanka after independence in 1948 was to provide free school and university education. However, after 2010 this policy was changed somewhat to allow recognized private sector and international universities to established and award degrees at a fee for those who wished to obtain them. Charges of such institutes are comparatively high. Thus, attraction of lower income categories to OUSL would be due to the affordable and easy payment scheme provided by OUSL (total Ca. SLR150,000.00 for 108 credits for the BSc degree). Similar results were seen in the Bangladesh Open University, where 58.3 percent of the learners belonged to the lower-middle-income group population (Anwarul et al., 2010).

Most of the students that registered for the BSc degree are unmarried (92 percent), employed (53 percent) (Figure 2) and belong to the late adolescent (48 percent age 18-22, 92 percent below 27 years) age category. The age at graduation of students of OUSL in 1996 showed that the majority of BSc graduates were less than 30 years (76 percent), Bachelor of Engineering Technology (BTech) graduates 31-41 years and that 58 percent of LLB (law) graduates ranged from 31-71 (Senarathne et al., 2001). As such it is clear that BSc graduates have been comparatively young even in the past. However, in the

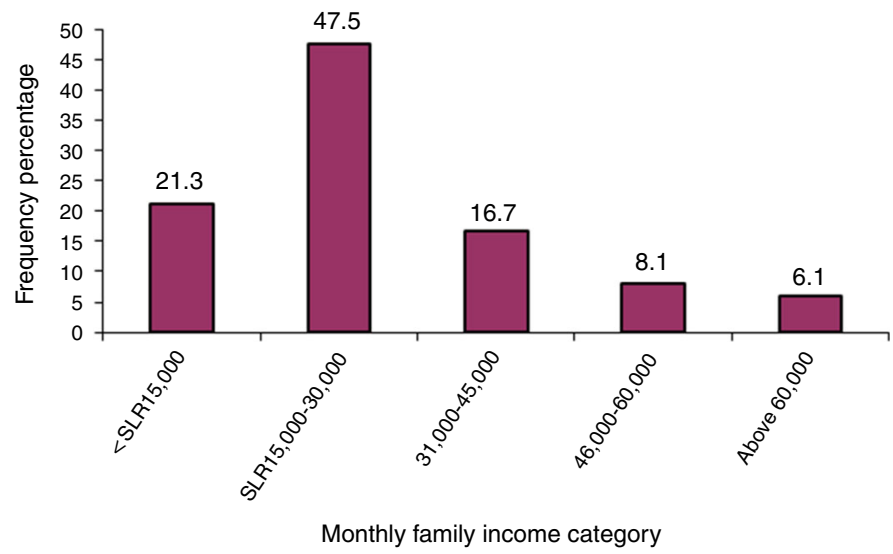

Figure 2.

Employment status as a frequency percentage of responses in newly registered $\mathrm{BSc}$ undergraduate of OUSL in 2014

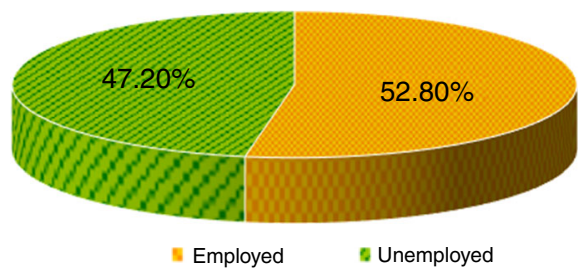


Open University of UK, the majority of undergraduates were aged between 31 and 60 and the average age was 43 years (Feinstein et al., 2007). However, a study carried out in 1997 in Sri Lanka (Jayathilake et al., 1997), to recognize characteristic features of OUSL students in comparison with conventional university students proved different. Our study in 2013 results in similar findings for students' characteristics but attraction of employed students to OUSL has increased compared to 1997. This is a good indication from the ODL concept point of view. However, one has to bear in mind that now there are more private universities. Some of these provide part time-based education; hence the competition faced by OUSL is higher. If the BSc program of OUSL continues to attract a majority of lower middle class or low income groups into the system, it will affect the students' intra-social interactions as well as the sustainability of the institution in the long run. Thus, the administration of the university should attempt to attract clients of other social strata as well. Most employment opportunities in Sri Lanka belong to the private sector and usually they consider the social strata, school, etc. of the candidate. If the OUSL is recognized as a university which caters mostly to low income social strata, it will affect the employability of OUSL, BSc graduates in the long run. In addition, retaining learners has always been an ongoing challenge for ODL institutions worldwide (Fozdar et al., 2006; Bandarage, 2016). According to OUSL statistics, 15 percent \pm 7 of new registrants of BSc program dropout without starting the academic activities as "Non-starters" (Bandarage, 2016). The student dropout rate has been high (ca.50 percent) in first and second years of BTech. study programs at OUSL (Dadigamuwa and Senanayake, 2012). It appears that a considerable percentage of undergraduates of OUSL give up their degree program without completion. One reason for this could be the "poor socio-economical background" of BSc undergraduates.

\section{Open ended component}

The primary purpose of this component of the questionnaire was to evaluate the existing knowledge on "ODL concepts" of BSc undergraduates of OUSL at initial registration. The open ended part consisted of four questions as: what is the teaching-learning process of OUSL; the main instructional media adapted by OUSL; the role of a teacher of OUSL; the role of a student of OUSL. The responses provided by students for each of these questions are tabulated from Tables I-IV, respectively.

\begin{tabular}{|c|c|c|}
\hline $\begin{array}{l}\text { Response } \\
\text { number }\end{array}$ & Response category (example of answers given) & $\begin{array}{c}\text { Response } \\
\text { frequency } \%\end{array}$ \\
\hline 1. & $\begin{array}{l}\text { Open distance system (does not strictly follow the basic qualification for entry as a } \\
\text { state university, any person can enter, not a full time program, most activities are } \\
\text { conducted during weekends); does not have a fixed age limit; can follow the } \\
\text { program while working }\end{array}$ & 51.97 \\
\hline 2. & Not answered for the question & $17.76 \%(81)$ \\
\hline 3. & $\begin{array}{l}\text { Self-study system (students have to study and learn concepts themselves, students } \\
\text { are self-motivated, academic achievements depend on self-ability and efficiency) }\end{array}$ & $12.06 \%(55)$ \\
\hline 4. & $\begin{array}{l}\text { Flexible learning system (a student can select the amount of workload favorable } \\
\text { to him) }\end{array}$ & $5.04 \%(23)$ \\
\hline 5. & $\begin{array}{l}\text { Conducting ODL system of OUSL is more student centered. Different media used to } \\
\text { facilitate students. Selection of subject units and amount is a student's own choice }\end{array}$ & $4.16 \%(19)$ \\
\hline 6. & No idea about the teaching-learning process at OUSL & $5.7 \%(26)$ \\
\hline 7. & $\begin{array}{l}\text { OUSL is conducting formal lectures, teaching system similar to other conventional } \\
\text { universities }\end{array}$ & $1.53 \%(07)$ \\
\hline & Teaching-learning process is strictly part time & $1.75 \%(08)$ \\
\hline
\end{tabular}

\section{Student characteristics and ODL knowledge}

45 
AAOUJ 12,1

46

The responses for the "nature of teaching-learning process of OUSL" clearly show that students have sufficient knowledge on this concept. For example, they have recognized that the teaching-learning process as an open distance system (51.97 percent), self-study system (12.06 percent), flexible learning (5.04 percent), and students centered (4.16 percent), respectively (Table I). Only, a very low amount of response frequencies (1.53 percent) were allocated as "OUSL is conducting formal lectures" similar to a conventional setup.

Aluwihare and De Silva (2016) state that about 86 percent BTech undergraduates of OUSL did not show sufficient knowledge on the open and distant teaching-learning process and concepts. Further, this was found to be a contributory factor in prolonging the time

\begin{tabular}{llc}
\hline $\begin{array}{l}\text { Response } \\
\text { number }\end{array}$ & Response category & $\begin{array}{c}\text { Response } \\
\text { frequency \% }\end{array}$ \\
\hline 1. & Mainly printed materials(developed by OUSL, and supplementary material) & $45.78 \%(174)$ \\
2. & Combination of different instruction media (printed material+educational & \\
video + internet, etc.) & $35.26 \%(134)$ \\
4. & Mainly internet-based education & $9.73 \%(37)$ \\
5. & Not answered the question & $8.68 \%(33)$ \\
5. & Manly educational video and electronic media & $0.52 \%(02)$
\end{tabular}

Table II. 2

BSc new registrants' perception of the main 3 instructional media used in OUSL

\begin{tabular}{llr}
\hline $\begin{array}{l}\text { Response } \\
\text { number }\end{array}$ & Response category & $\begin{array}{c}\text { Response } \\
\text { frequency \% }\end{array}$ \\
\hline 1. & $\begin{array}{l}\text { OUSL teacher recognized as "a helper for studies," "a good counselor," "a } \\
\text { facilitator "or "a good advisor" }\end{array}$ & $56.9 \%(185)$ \\
2. & $\begin{array}{l}\text { Formal lecturer role: teaching subject matter like in our school class room, } \\
\text { formal teacher role, should be a lecturer like in other government universities }\end{array}$ & $20.3 \%(66)$ \\
3. & Not answered the question & $17.23 \%(56)$ \\
4. & No Idea on the role of the OUSL teacher & $2.76 \%(09)$ \\
5. & Teacher should be a very friendly, kind hearted person, should able to make & \\
6. & interactions as well as emotional attachments with students & $2.46 \%(08)$ \\
& OUSL teacher should play multiple roles as a good teacher, guide, helper, etc. & $0.3 \%(01)$ \\
\hline
\end{tabular}

\section{Table III.}

The role of the teacher at OUSL: as perceived by BSc new registrants

\section{Response} number

Response category

1. Self or independent learner: OUSL student should have the ability to explore knowledge himself. "My palm is only a shade for my head"

2. Prefer conventional role: should be a good group worker, learning collectively, making good relationships among university teacher as well as within students

$3 \quad$ No Idea about student role

4. The OUSL student should be a good time manager: Ability to balance time and manage arise conflicts in different roles (university, working place and home)

5. Exam-oriented mentality: somehow OUSL students should be able to get through exams within a minimum period for future development

6. Not answer the question

Table IV.

BSc new registrants' perception of

8. "his/her role as an OUSL student"
Should be a hard worker and a target-oriented person

Should have developed a balanced personality to solve and tolerate difficulties in the ODL endeavor, should be a different role player (as an employer, as an undergraduate, as a husband/wife/family member)
Response

frequency $\%$

$22.6 \%(103)$

$19.15 \%(72)$

$6.38 \%(24)$

$5.85 \%(22)$

$3.19 \%$ (12)

$1.32 \%(05)$ 
duration taken for completing the degree. However, result of this study has recognized that in contrast BSc new registrant of OUSL have sufficient knowledge on ODL concepts (Table I). Efficient counseling and orientations programs can be recommended for those who show poor perception of the ODL teaching-learning process.

Generally, the OUSL uses printed material as instruction media and to a lesser extent electronic aids as supplementary material. More response frequencies (45.7 percent) clearly highlight the existing condition in relation to the instructional material. The latest statistics issued by the Telecommunication Regulatory Commission of Sri Lanka show that active internet users have increased up to more than 5 million and the number of mobile broadband connections has doubled each year from 2009 to 2015 (Internet usage of Sri Lanka, 2016). The computer literacy of the younger generation (aged 15-29) in Sri Lanka is quite high. Of the 18-24 age group 65 percent could manage basic functions of the computer as opposed to the 25-29 year olds where only 43 percent demonstrated knowledge in computer usage (De Silva et al., 2013). We found that more than 92 percent of the BSc undergraduates registered for OUSL are below 27 years age, and as such should be computer literate. In addition, responses for the open ended part of the questionnaire recognized the main instruction media of OUSL as "purely internet" (9.73 percent) or a "mixture of internet and other electronic or printed material" (35.26 percent) (Table II). The answer may indicate their subconscious preference to use electronic media including the internet as instructional media. In this context OUSL is still not on par with the use of technology by the younger generation. Hence, this study recommends the increase of online teaching-learning processes for BSc undergraduate of OUSL.

Responses to the "role of the teacher at OUSL" can be summarized into six categories (Table III). The majority of response frequencies correctly recognized the role of an ODL teacher as "a helper"; a "good counselor," a "facilitator" or "an adviser" (56.9 percent).But quite a large frequency percentage (37.5 percent) of responses recognized the role of an ODL teacher to be similar to the role played by a conventional "teacher" or did not respond to the question.

Most of BSc undergraduates of OUSL are comparatively young and below 27 years of age. After facing the highly competitive G.C.E. (A/L) examination, most do not gain the opportunity of entering a conventional state university. From among those who are eligible for university education, it is actually only 28.87 percent that qualify to enroll at conventional state universities in biological science discipline and only 38.12 percent in physical science in the year 2012 (UGC-Sri Lanka, 2016). The majority of students, who perform relatively well at G.C.E. (A/L) do not get the opportunity to enter state universities, due to the limitation of resources and state higher education institutes in the country. Further, 38.05 percent of students, did not qualifying for university/tertiary education based on G.C.E. (A/L) 2012 results (Department of Examination, 2016). This clearly shows that the larger percentage of students either do not qualify G.C.E. (A/L) exam or even if qualified do not get the opportunity to gain (state) university entrance. These students either select suitable middle class employment or directly enter for further studies at private institutes or OUSL. Even those who are employed may select higher education at OUSL.

Our study results shows that, 48 percent of new registrants are between the ages 18 and 22 ; and therefore, fresh school leavers. The role played by secondary school teachers would still be fresh in the minds of new registrants. Hence they prefer close contact with teachers. Basically, ODL students are physically isolated. However, psychologically, adolescent students prefer and need emotional contact with teachers or their peers. Situations such as these make students distressed or in the long run even give up the study program. It has been identified that 64 percent of BSc undergraduate of OUSL are psychologically distressed (Kuruppuarachchi et al., 2012a, b). This could be due to physical isolation or problems faced during adjustment to the ODL system of OUSL or both. Therefore it is recommended that appropriate orientation and counseling programs be conducted during characteristics and ODL knowledge 
AAOUJ

12,1

48

initial registration time (of BSc undergraduates) are strengthened to overcome these issues. The major components of the teaching-learning process of the ODL system are course development and delivery. During course development, more attention is given to develop knowledge or for the cognitive development of the students. The course delivery part of the ODL system therefore, should mainly consider the development of skills, attitudes and values. In the long run the teaching-learning process of OUSL should be reformed to fulfill student's psychological needs, in addition to the knowledge-based domains. Hence, course delivery components such as practical, day schools, and other extracurricular work should be reformed to provide more interaction between teachers and students as well as among students. For example, peer interaction sessions, active learning, cooperative learning or group learning techniques can be strengthened to develop soft skills and values and enhance social interaction to eliminate the social isolation of adolescent BSc undergraduates of OUSL.

According to the Sri Lanka Qualification Framework (2015), 12 learning outcomes should be achieved by any undergraduate of a Sri Lankan University. This includes only 25 percent for knowledge-based domains and the remaining 75 percent are mainly targeted toward attitude and skills development. Hence, OUSL too has to reform its teaching-learning process to include more attitude and skills development while maintaining its identity as an ODL institute.

The responses on "The role of OUSL students" could be summarized into eight categories. The relevant response frequencies are displayed in Table IV. Results showed that mainly response category number 1 (36.7 percent), 4 (6.38 percent), 7 (3.19 percent) and 8 (1.32 percent) (total 47.59 percent) represent clear ODL concepts on the "role of an ODL student." However, the responses of students indicate that the majority (52.1 percent) did not have a clear idea of this concept.

Central to Carl Rogers' personality theory (Rogers, 1959) is the notion of self or self-concept. This is defined as "the organized, consistent set of perceptions and beliefs about oneself." The self is the humanistic term for who we really are as a person. According to Carl Rogers, the main duty even of a counselor is to help the client understand "himself." As such the students should be helped to get a more clear perception of their responsibility and role in the ODL system. Students should be made to realize that their success in the ODL setup is clearly dependant on their own efforts, and even more so that in a conventional University setup.

The Sri Lankan school education system is mainly knowledge oriented. The G.C.E. (A/L) science discipline is a highly competitive and exam-oriented teaching-learning process. A "spoon feeding system" has been developed by A/L teachers as well as private tutors. This maybe reflected in the BSc undergraduates' inability to clearly recognize ones' role and responsibility as an ODL student. The new teaching-learning process, the physically isolated nature of the ODL system along with other problems faced during adjustment to the new system would seriously affected the new registrant to the OUSL.

ODL students are more likely to have insecurities about learning. New registrant are particularly vulnerable, as they struggle to establish study habits, time management and maintain motivation. The adjustment difficulties, financial difficulties, limited access to resources, and conflict between education and family life or work place, etc., could lead to further insecurities (Owens et al., 2009).

Due to these reasons, the academic and administrative structure of OUSL, especially in the Faculty of Natural Sciences should not be restricted to the "conventional ODL concepts and methodologies." It should be flexible, to promote students' interactive sessions, peer learning, group learning, active learning or collaborative learning systems which can be include into course delivery. In addition, the BSc undergraduate should be trained to recognize "self-concepts" and "self-learning concepts" during the time of initial registration by strengthening fruitful orientation and counseling programs. In addition to the limited existing 
on-campus orientation and academic counseling programs for new registrants in the Faculty of Natural Sciences, it has recently (2014) introduced "Peer-Assisted Study Sessions". These are conducted with the help of existing and newly graduated OUSL students as young mentors. This will help students to developed social and academic interactions and share experiences gained by past students (Bandarage et al., 2015). Unfortunately, students' participation in such academic support work has not been encouraging. Hence, new methodologies need to be developed to improve attitudes and social skills of OUSL, BSc undergraduates by way of introducing group assignments, presentations and case studies, etc. which are considered as a component of the continuous assessments.

\section{Conclusions/recommendations}

In conclusion, the majority of BSc undergraduates of OUSL represent the employed, late adolescent lower middle class. Prior knowledge on ODL concepts were developed by the majority of BSc undergraduates while not properly recognizing the "role of an ODL student." Hence, more attention should be paid to make students aware of their role in the ODL system, in order to succeed at OUSL. In addition, the following recommendation can be highlighted from the findings of the study:

- Increasing online-based teaching-learning processes for BSc undergraduate of OUSL.

- To fulfill student's psychological needs, the ODL delivery components should be reformed to provide more interaction between teachers and students as well as among students, i.e. active learning, cooperate learning, group learning, case studies, etc. in limited contact sessions.

- A fruitful orientation and counseling program during the initial registration period to adjust to "self-learning," "ODL methodologies," "self-management" to work efficiently in physically isolation.

- The teaching-learning system of OUSL should not be restricted to the "Conventional ODL concept and methodologies" and should be flexible to promote possible students interactions.

- The academic and administrative structure of the OUSL especially in the Faculty of Natural Sciences should try to diversify its clientele. While commending the institution for providing opportunities for the less privileged, the university should make an effort to attract clients of diverse social classes for the long-term sustainability of the institute.

The majority of studies on ODL focus on the nature or improvement of the educational process or the output (the graduate). However, as the output depends on both the process and the input (students that enroll) it is equally important to pay adequate attention to this aspect and conduct such surveys on its cliental periodically as well. This will enable the institute to formulate/modify its policies on educational administration, program development, delivery, student welfare, etc. to better cater to its cliental and in the process lead to the betterment of the institution.

\section{References}

Aluwihare, S. and De Silva, S. (2016), "Prolonged time taken to complete the degree programmes at the faculty of engineering technology of the Open University of Sri Lanka barriers and remedies", Asian Association of Open Universities Journal, Vol. 11 No. 2, pp. 136-148.

American Association for Public Opinion Research (2000), Standard Definitions: Final Dispositions of Case Codes and Outcome Rates for Surveys, 2nd ed. (electronic version), AAPOR, Ann Arbor, MI. 
AAOUJ

12,1

Anwarul, A., Sharker, D. and Numan, S. (2010), "Learners' demographic profiles and attitude towards the learners of open school at Bangladesh Open University, a study", Formal Education-Open Schooling, Pan-Commonwealth Forum 6 (PCF6), available at: http://oasis.col.org/handle/ 11599/2090 (accessed January 18, 2017).

Bandarage, G. (2016), "Prevalence and the effect of non-starters on course completion rates of the BSc programme. A preliminary study", Proceedings of the Annual Academic Sessions, The Open University of Sri Lanka, Colombo, November 17-18, pp. 1-4.

Bandarage, G., Edirisinghe, E.A.D.N.D., Rajendra, J.C.N., Siriwardena, K.D.V.F., Somerathne, S., Tantrigoda, R.U. and Wattavidanage, J. (2015), "Effectiveness of a modified version of peer assisted study session in improving academic performance", Proceedings of the Annual Academic Sessions, The Open University of Sri Lanka, Colombo, November 19-20, pp. 1-4.

Barefoot, B.O. (2004), "Higher education revolving door; confronting the problem of student dropouts in US colleges and university", Open Learning, Vol. 19 No. 1, pp. 9-18.

Carnevale, D. (2000), "Online instructor takes step to reduce drop out rate. The chronicle of higher education", available at: www.Chronicle.com (accessed January 18, 2017).

Dadigamuwa, P.R. and Senanayake, S. (2012), "Motivating factors that affect enrolment and student performance in an ODL engineering programme", The International Review of Research in Open Distance Learning, Vol. 13 No. 1, pp. 238-249.

De Silva, W.I., Kodikara, P. and Somarathne, R. (2013), "Sri Lankan youth and their exposure to computer literacy", Sri Lanka Journal of Advanced Social Studies, Vol. 3 No. 1, pp. 27-52.

Department of Census and Statistics (2013), "Household income and expenditure survey - 2012/13, preliminary results", available at: www.statistics.gov.lk/hies/hies201213buletineng.pdf (accessed May 17, 2016).

Department of Examination (2016), "Performance of candidates - G.C.E. (O/L) and G.C.E. (A/L), 2010-2014", available at: www.statistics.gov.lk/pocket\%20book/chap13.pdf (accessed August 16, 2016).

Feinstein, L., Anderson, T.M., Hammond, C., Jamieson, A. and Woodley, A. (2007), "The social and economic benefits of part-time, mature study at Birkbeck College and the Open University, UK", project report, OUUK, Birkbeck, London.

Fozdar, B.I. and Kumar, L.S. (2006), "Teaching chemistry at Indira Gandhi national open university", Turkish Online Journal of Distance Education, Vol. 7 No. 2, pp. 80-89.

Fozdar, B.I., Kumar, L.S. and Kanna, S. (2006), "A survey of a study on the reasons responsible for student dropout from the bachelor of science programme at Indira Gandhi national open university", International Review of Research in Open and Distance Learning, Vol. 7 No. 3, pp. 1-14.

Internet usage of Sri Lanka (2016), available at: www.digitalmarketer.lk/internet-usage-statistics-in-srilanka (accessed August 15, 2016).

Jayathilake, B.G., Leckamge, G.D. and Weerasinghe, B. (1997), "Survey of student characteristics at the open university: a comparison with conventional universities in Sri Lanka", OUSL Journal, Vol. 1 No. 1, pp. 45-63.

Keegan, D. (1996), Foundations of Distance Education, 3rd ed., Routledge Publishers, London.

Kuruppuarachchi, K.A.J.M. and Gunerathne, B.C. (2014), "Student perceptions on newly introduced continuous assessment test (CAT) system for faculty of natural sciences", Proceedings of the Annual Academic Sessions, The Open University of Sri Lanka, Colombo, November 27-28, pp. 295-299.

Kuruppuarachchi, K.A.J.M., Dias, P. and Kannangara, C.N. (2016), "Evaluation of input of open distance learning (ODL) processing system (PS) of the Open University of Sri Lanka (OUSL): detecting influential factors for registering students for BSc degree programme", Proceedings of the Annual Academic Sessions, The Open University of Sri Lanka, Colombo, November 17-18, pp. 5-9.

Kuruppuarachchi, K.A.J.M., Somerathne, S., Madurapperuma, B.D. and Talagala, I.M.M. (2012a), "Factors associated with psychological distress among BSc undergraduates of the Open University of Sri Lanka", Proceedings of the Annual Academic Sessions, The Open University of Sri Lanka, Colombo, February 27-28, pp. 52-55. 
Kuruppuarachchi, K.A.J.M., Somerathne, S., Madurapperuma, B.D. and Talagala, I.M.M. (2012b), "Stressful events and solutions: a case study with BSc undergraduates of the Open University of Sri Lanka”, Proceedings of the Annual Academic Sessions, The Open University of Sri Lanka, Colombo, February 27-28, pp. 56-59.

Nigam, A. and Joshi, V. (2007), "Science education through open and distance learning at higher education level”, Turkish Online Journal of Distance Education, Vol. 8 No. 4, pp. 20-33.

Owens, J., Hardcastle, L. and Richardson, B. (2009), "Learning from a distance: the experience of remote students", International Journal of E-Learning \& Distance Education, Vol. 23 No. 3, pp. 53-74.

Rogers, C. (1959), "A theory of therapy, personality and interpersonal relationships, ad developed in the client-centered framework", Formulations of the Person and the Social Context in Koch, S. (Ed.), Psychology: A Study of a Science Study, Vol. 1, McGraw-Hill, New York, NY, pp. 184-256.

Senarathne, L.K., De Costa, S. and Bandara, N.J.G.J. (2001), "A survey of graduates of the Open University of Sri Lanka”, OUSL Journal, Vol. 3 No. 1, pp. 6-29.

Sri Lanka Qualification Frameworks (2015), "Sri Lanka qualification frameworks-upgraded version, university grant commission of Sri Lanka", ISBN 978-955-4510-01-2, The World Bank Funded, Higher Education for Twenty First Century (HETC) Project of the Ministry of Higher Education, Nugegoda, pp. 1-38.

Tantrigoda, R.U., Wattavidanage, J., Rajendra, J.C.N., Wickramasinghe, B.K.L., Edirisinghe, N. and Bandarage, G. (2014), "Making significant others partners in motivating freshman of the BSc degree programme at the Open University of Sri Lanka: a preliminary study", Proceedings of the Annual Academic Sessions of the Open University of Sri Lanka, Colombo, November 27-28, pp. 291-294.

UGC-Sri Lanka (2016), "Sri Lanka university statistics", available at: www.ugc.ac.lk/ en/component/ content/ article/1418-sri-lanka-university-statistics-2013.html (accessed August 15, 2016).

\section{Corresponding author}

K.A.J.M. Kuruppuarachchi can be contacted at: kajmkuruppu@gmail.com

For instructions on how to order reprints of this article, please visit our website: 